\title{
Acremonium Potronii Associated Pneumonia in an Allogeneic Stem Cell Transplantation Recipient
}

\author{
Allojeneik Kök Hücre Nakli Yapılan Bir Olguda Gelişen Acremonium Potronii iliş̧kili Pnömoni
}

Ramazan Civelek ${ }^{1}$, Merih Kızıl Çakar², Zeynep Arzu Yegin² ${ }^{2}$, Gonca Erbaş ${ }^{3}$, Özlem Güzel Tunçcan ${ }^{4}$, Ayşe Kalkancı ${ }^{5}$

Gülsan Türköz Sucak ${ }^{2}$

${ }^{1}$ Gazi University Faculty of Medicine, Department of Internal Medicine, Ankara, Turkey

${ }^{2}$ Gazi University Faculty of Medicine, Department of Hematology, Ankara, Turkey

${ }^{3}$ Gazi University Faculty of Medicine, Department of Radiology, Ankara, Turkey

${ }^{4}$ Gazi University Faculty of Medicine, Department of Infectious Diseases, Ankara, Turkey

${ }^{5}$ Gazi University Faculty of Medicine, Department of Microbiology, Ankara, Turkey

\section{ABSTRACT}

Infections are one of the major causes of morbidity and mortality after allogeneic hematopoietic stem cell transplantation. Clinically significant graft versus host disease, steroid therapy, cytomegalovirus infection, recurrent neutropenia and relapsed/refractory disease are the recognized risk factors for invasive fungal infections. Acremonium, which is a large polyphyletic fungal genus, is present in soil, insects, plants and other environmental substrates. Disseminated infections are rare with the reported cases limited to immunocompromised patients with a large clinical spectrum including pneumonia, arthritis, osteomyelitis, endocarditis, peritonitis, meningitis and sepsis. Acremonium species present low susceptibility to most antifungals including imidazoles, fluorocytosine and amphotericin B. For the clinically relevant species, the minimum inhibitory concentrations for all antifungal agents are high, except terbinafine. As Acremonium spp grow slowly, cultures should be kept for at least 2 weeks to ensure detection of a positive sample. Clinicians should be aware that Acremonium spp, particularly A. Potronii, might be one of the causative fungi of systemic infection in severely immunocompromised allogeneic hematopoietic stem cell transplantation recipients.

Key Words: Acremonium potronii, pneumonia, stem cell transplantation, multiple myeloma, immunosuppression

Received: 01.13 .2016

Accepted: 06.29.2016

\section{ÖZET}

Enfeksiyonlar allojeneik kök hücre nakli yapılan hastalarda önemli morbidite ve mortalite nedenidir. Graft versus host hastalığı, steroid tedavisi, sitomegalovirus enfeksiyonu, nötropeni ve relaps/dirençli hastalık invaziv fungal enfeksiyonlar için bilinen risk faktörleri arasındadır. Acremonium toprakta, böceklerde, bitkilerde ve diğer çevresel yapılarda bulunabilen bir mantar türüdür. Nadir olarak immunsupresif hastalarda pnömoni, artrit, osteomyelit, endokardit, peritonit, menenjit ve sepsis gibi dissemine enfeksiyonlara neden olabilmektedir. İmidazol, florositozin, amfoterisin B gibi antifungal ajanlara karşı duyarlıı̆̆ı düşüktür. Terbinafin dışındaki tüm antifungal ajanlar için minimum inhibitör konsantrasyonu yüksektir. Yavaş üreme özelliğine sahiptir, bu nedenle üremenin sağlanması için kültürler en az iki hafta süreyle bekletilmelidir. Acremonium, özellikle olgumuzda tespit edilen Acremonium potronii, allojeneik kök hücre nakli yapılan ağır immunsupresif hastalarda gelişen sistemik mantar enfeksiyonlarında düşünülmesi gereken bir mantar türüdür.

Anahtar Sözcükler: Acremonium potronii, pnömoni, kök hücre nakli, multipl myelom, immunsupresyon

Geliş Tarihi: 13.01 .2016

Kabul Tarihi: 29.06.2016

\section{INTRODUCTION}

Multiple myeloma (MM) remains to be an incurable disease despite novel treatment strategies. Allogeneic hematopoietic stem cell transplantation (AHSCT) is the only treatment option with a curative potential so far. However, the potential cure comes at a price; transplant related mortality $(1,2)$. Infections represent up to $63 \%$ of the causes of death in myeloablative AHSCT recipients. Early infections are less common in non-myeloablative AHSCT recipients as a result of less mucositis and neutropenia. However, patients may remain susceptible to opportunistic infections for an extended period in the post-transplant course due to the slow recovery of T cell immunity (3-5). Disseminated Acremonium infections are rare with the reported cases limited to immunocompromised patients with a large clinical spectrum including

pneumonia, arthritis, osteomyelitis, endocarditis, peritonitis, meningitis and sepsis (6-10).

Here, we present a case of MM who underwent non-myeloablative AHSCT and developed pneumonia associated with Acremonium potronii along with graft versus host disease (GVHD) and cytomegalovirus (CMV) reactivation.

\section{CASE REPORT}

A 61-year-old male patient, who was diagnosed as Stage IIIA MM, received an autologous HSCT after 6 cycles of VAD (Vincristine, Doxorubicine and Dexamethasone) chemotherapy. Eight cycles of bortezomib/dexamethasone and a lenalidomide-based combination were administered post autologous HSCT for progressive disease. He received a non-myeloablative AHSCT from his HLA identical brother. 
On day +180 , he developed skin and gastrointestinal GVHD and was started on cyclosporine A, mycophenolate mofetil and methyl prednisolone with posaconazole prophylaxis. On day +190 , he was hospitalized due to neutropenic fever. He had CMV reactivation with a CMV polymerase chain reaction (PCR) level of 1380 copies/mL. Piperacillin-tazobactam and gancyclovir were commenced. A progressive increase in CMV DNA level reaching up to 26000 copies/mL on gancyclovir treatment was observed. Early antiviral modification with foscarnet resolved CMV infection. However, the patient remained to be febrile and hypoxic. Piperacillin-tazobactam was stopped and an extended antibacterial treatment including meropenem and linezolid was commenced. High resolution chest tomography (HRCT) revealed peribronchovascular patchy areas of consolidation with air bronchograms (Figure 1 \& 2). Bronchoscopy was not feasible because of refractory thrombocytopenia. Based on radiological evidence, bacterial bronchopneumonia was the most possible diagnosis, however Pneumocytis jirovecii or fungal infection could not be ruled out.

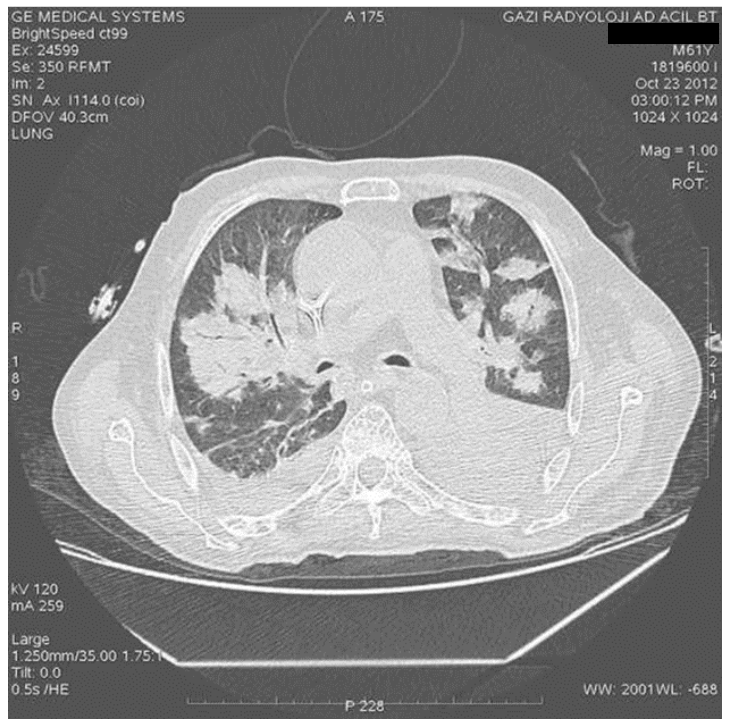

Figure 1 Peribronchovascular patchy areas of consolidation with air bronchograms on high resolution chest tomography (horizontal section)
Prophylactic posaconazole was stopped, empiric voriconazole and trimethoprim sulfamethoxazole were started. Soon after, he was transferred to the intensive care unit for mechanic ventilation support. A few days after his death, Acromonium potronii grew in his sputum culture which was taken before intubation. The morphologic identification of Acremonium on genus level was done according to colony morphology on Sabouraud dextrose agar (SDA) plates. Microscopic evaluation of the colonies was also performed for identification. The genotypic identification was done by using DNA sequencing. $500 \mathrm{bp}$ region of the fungal internal transcribed spacer (ITS) DNA was sequenced in ABI Prism TM 310 Genetic Analyzer (Applied Biosystems, USA). The sequence data analyzed using the National Center for Biotechnology Information (NCBI, Bethesda, Md.,USA) BLAST system (available at http://www.ncbi.nlm.nih.gov/BLAST//). Fungal DNA isolated from colony was identified as Acremonium potronii. Antifungal susceptibility was performed according to reference methods proposed by Clinical Laboratory Standards Institute (CLSI) by M38A microdilution method. Amphotericin MIC value was $2 \mu \mathrm{g} / \mathrm{ml}$, it was $4 \mu \mathrm{g} / \mathrm{ml}$ for voriconazole, $32 \mu \mathrm{g} / \mathrm{ml}$ for fluconazole and 0.5 $\mu \mathrm{g} / \mathrm{ml}$ for itraconazole.

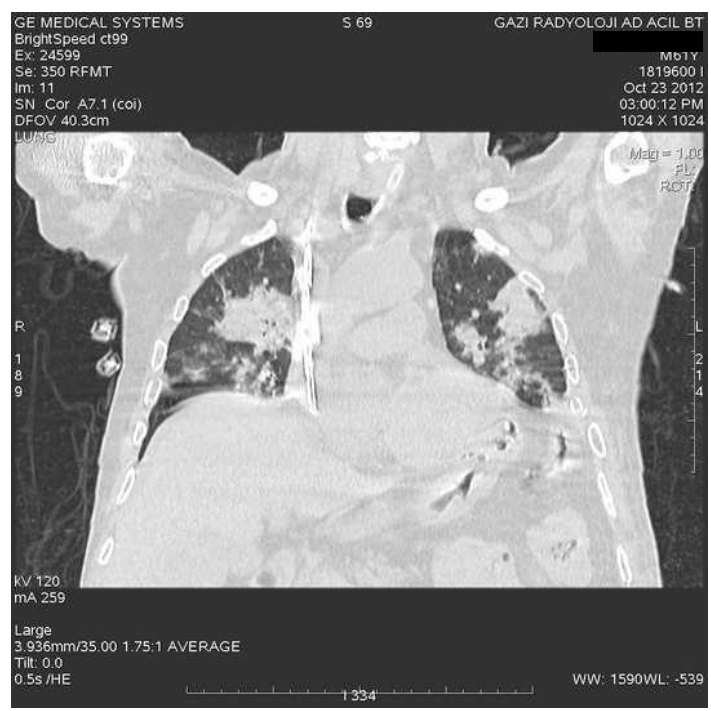

Figure 2 Peribronchovascular patchy areas of consolidation with air bronchograms on high resolution chest tomography (sagittal section)

\section{REFERENCES}

1.Reynolds C, Ratanatharathorn V, Adams P, Braun T, Silver S, Ayash L, Carson E, Eisbruch A, Dawson LA, McDonagh K, Ferrara J, Uberti J. Allogeneic stem cell transplantation reduces disease progression compared to autologous transplantation in patients with multiple myeloma. Bone Marrow Transplant 2001;27:801-7.

2.Efebera YA, Qureshi SR, Cole SM, Saliba R, Pelosini M, Patel RM, Koca E, Mendoza FL, Wang M, Shah J, Alousi A, Hosing C, Popat U, Kebriaei P, Anderlini P, Khouri IF, Champlin $\mathrm{R}$, Giralt S, Qazilbash $\mathrm{MH}$. Reduced-intensity allogeneic hematopoietic stem cell transplantation for relapsed multiple myeloma. Biol Blood Marrow Transplant 2010;16:1122-9.

3.Safdar A, Rodriguez GH, Mihu CN, Mora-Ramos L, Mulanovich V, Chemaly RF, Champlin $\mathrm{RE}$, Khouri I. Infections in non-myeloablative hematopoietic stem cell transplantation patients with lymphoid malignancies: spectrum of infections, predictors of outcome and proposed guidelines for fungal infection prevention. Bone Marrow Transplant 2010;45:339-47.

4.Marr KA. Delayed opportunistic infections in hematopoietic stem cell transplantation patients: a surmountable challenge. Hematology Am Soc Hematol Educ Program 2012;2012:265-70.

5.Hagen EA, Stern H, Porter D, Duffy K, Foley K, Luger S, Schuster SJ, Stadtmauer EA, Schuster MG. High rate of invasive fungal infections following nonmyeloablative allogeneic transplantation. Clin Infect Dis 2003;36:9-15.

6.Yamazaki R, Mori T, Aisa Y, Nakazato T, Mihara A, Ikeda Y, Okamoto S. Systemic infection due to Acremonium after allogeneic peripheral blood stem cell transplantation. Intern Med 2006;45:989-90.

7.Ioakimidou A, Vyzantiadis TA, Sakellari I, Arabatzis M, Smias C, Douka V, Velegraki A, Anagnostopoulos A, Malissiovas N. An unusual cluster of Acremonium kiliense fungaemias in a haematopoietic cell transplantation unit. Diagn Microbiol Infect Dis 2013;75:313-6.

8. Herbrecht R, Letscher-Bru V, Fohrer C, Campos F, Natarajan-Ame S, Zamfir A, Waller J. Acremonium strictum pulmonary infection in a leukemic patient successfully treated with posaconazole after failure of amphotericin B. Eur J Clin Microbiol Infect Dis 2002;21:8147.

9.Schell WA, Perfect JR. Fatal, disseminated Acremonium strictum infection in a neutropenic host. J Clin Microbiol 1996;34:1333-6.

10.Perdomo H, Sutton DA, García D, Fothergill AW, Cano J, Gené J, Summerbell RC, Rinaldi MG, Guarro J. Spectrum of clinically relevant Acremonium species in the United States. J Clin Microbiol 2011;49:243-56. 